\title{
鳥取海岸の人工リーフ周辺の海底地形の変化について

\author{
Bathymetric change around artificial reefs along Tottori coast
}

\author{
木村 晃 $^{1} \cdot$ 大野賢 $^{2} \cdot$ 中村真智子 $^{3}$ \\ Akira KIMURA, Kenichi OHNO and Machiko NAKAMURA
}

\begin{abstract}
This study deals with bathymetric changes around artificial reefs (AF) which have been constructed along Tottori sand dune coast. Three types of AF groups are investigated applying ARGUS method. In one AF group with a wide alongshore interval, sand bars which are a part of the local alongshore bar system appear between the intervals. In AF group with small intervals, offshore concave sand bars appear between AF intervals inside the AF line. Rip channel appears shore side of each bar and the channel changes the direction toward the center of each AF after it meets with the neighboring channel. A large alongshore sand bar appears from one of the AF interval outside the AF line. It may show that there is a sand movement from inside the AF line.
\end{abstract}

\section{1. はじめに}

人工リーフは主に離岸堤の景観に対する欠点を改善す る目的で考えられた構造物で, すでに我が国では700基 以上が設置されている. 人工リーフの特性については, 反射率，透過率，周辺の流れなどについては，実験，数 值計算などによる検討が行われているものの, リーフ周 辺の海底地形に及ぼす中・長期の影響に関する報告, 十 分な検討が行われている訳ではない。これは人工リーフ が通常砕波带付近に設置されるため, 冬期の測量が困難 であることにもよる．本研究は鳥取周辺で，隣接するリ ーフの数，堤長，開口部間隔などの異なる 3 か所の人工 リーフを対象としてARGUS法により3〜6年にわたり観 測を行い（木村ら，2006，2007，2008，2009），周辺の 海底地形の変化について観測結果の1部を示したもので ある。

観測は鳥取砂丘海岸の(1)一つ山，(2)岩戸，(3)浦富海岸 の人エリーフを対象として行った。 それぞれの人工リー フの諸元は表-1のとおりである.

解析に用いたARGUS 法は砕波による気泡を利用して 海底の浅瀬（砂堆, 岩礁）の位置, 水深などを検討する 方法である。各点の観測は(1)は1日1回，(2)は1日1回 (一つ山観測点), および週 1 回 (岩戸観測点), (3)は週 1

表-1 人エリーフの諸元

\begin{tabular}{c|c|c|c|c|c}
\hline 番号 & 堤長 & 開口幅 & 離岸距離 & 天端水深 & リーフ数 \\
\hline (1) & $200 \mathrm{~m}$ & $350 \mathrm{~m}$ & $150 \mathrm{~m}$ & $0 \mathrm{~m}$ & 2 \\
\hline (2) & $200 \mathrm{~m}$ & $100 \mathrm{~m}$ & $200 \mathrm{~m}$ & $0 \mathrm{~m}$ & 6 \\
\hline (3) & $400 \mathrm{~m}$ & $100 \mathrm{~m}$ & $250 \mathrm{~m}$ & $2 \mathrm{~m}$ & 2 \\
\hline
\end{tabular}

\begin{tabular}{llll}
\hline 1 & 正会員 & 工博 & 鳥取大学名誉教授 \\
2 & 正会貝 & 博(工) & $\begin{array}{l}\text { 鳥取大学准教授総合メディア基盤センター } \\
3\end{array}$ \\
ケイズ
\end{tabular}

回行った，観測点の標高は一つ山が $70 \mathrm{~m}$, 岩戸，浦富が 約 $60 \mathrm{~m}$ である。

\section{2. 単独の人エリーフの場合}

図-1は鳥取海岸の人工リーフ (1), (2)）の設置位置の 図である.人工リーフには仮に西（左）側より順にNo.1 からNo.8 まで番号をつけて示す. 図中でNo.1 と No.2, No.2 と No.3の人工リーフの設置間隔は比較的大きく, そ れぞれ単独の人工リーフとみなしうるものと考えて検討 を行った.この2つの人エリーフは付近の inner barとほ ぼ同じ位置に設置されており, barは人工リーフ付近もし くはそれよりやや沖側に存在し, 人工リーフ沖側斜面が 波の打ち达み点となっている. No.1の人工リーフでは巻 き波型の砕波による波乗り現象のため人工リーフの標識 ブイの係留鎖が時折切断する. 写真-1 (a)〜 (f) はNo.2 の人エリーフ周辺のARGUS 画像である. 写真中央左側 に人工リーフ (長さ $200 \mathrm{~m})$ が設置されている. 中央右側 にNo.3, No.4の人工リーフが写っている. 図-2は写真-1 の説明のための図である. 人エリーフの長さは $200 \mathrm{~m} て ゙$ ある. 海底地形の変化は年によって少しずつ異なるが, 著者らが観測を開始した 2004 年から現在までのところ， ここに示した 2007 年とおおむね同じ周年変化を繰り返し 示している. 写真で（a），(b）は高波浪期，（c）は高波 浪期から静穏期への移行期，（d）は静穏期，（e）は静穏 期から高波浪期への移行期，および（f）は高波浪初期の ものである。ただし（d）は静穏期であっても台風など 例外的に高波浪が現れた場合の観測結果である.

(a) 高波浪の開始時期で, 人工リーフ沖側の砂州はこの 付近のinner barと同じ位置に現れている. その岸側に No.2からNo.3にかけて沖側に凹状のbarが現れている. このように隣接する人工リーフの間には高波浪期凹状 のbarが見られることが多い. 


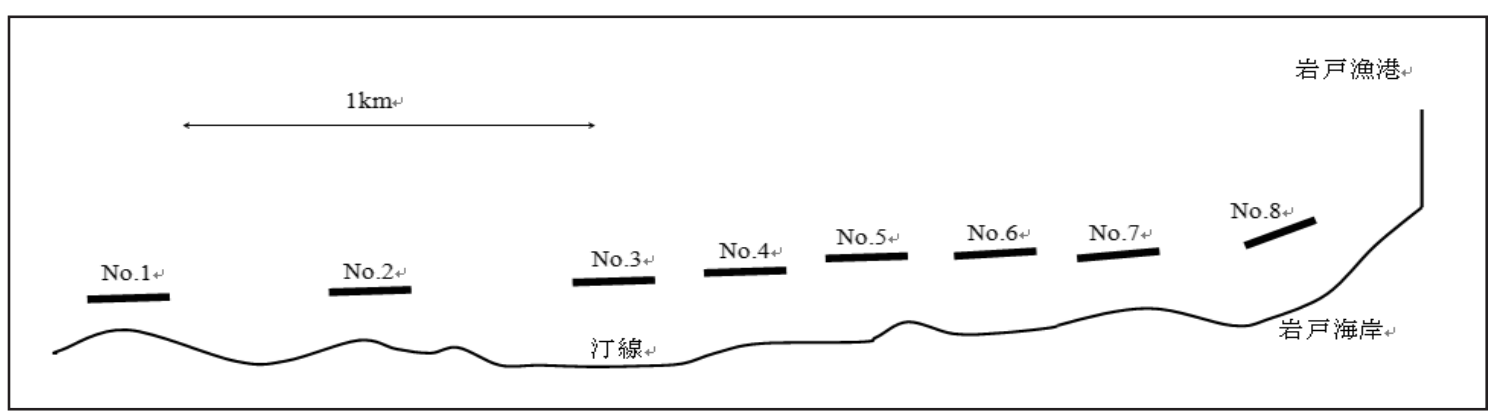

図-1＼cjkstart鳥取海岸の人工リーフ配置（模式図）

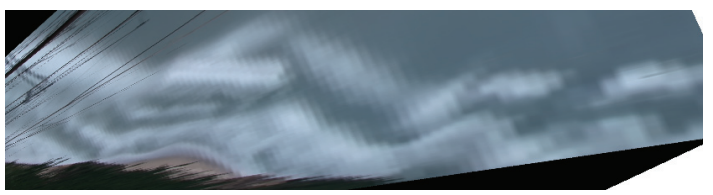

(a) 1 月 10 日

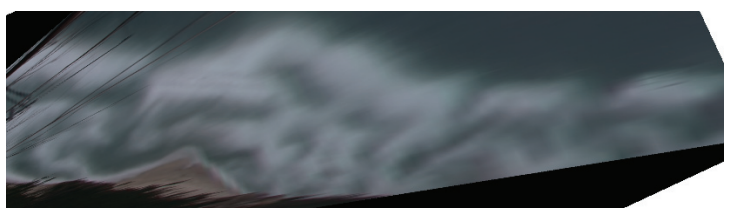

(b) 2 月 24 日

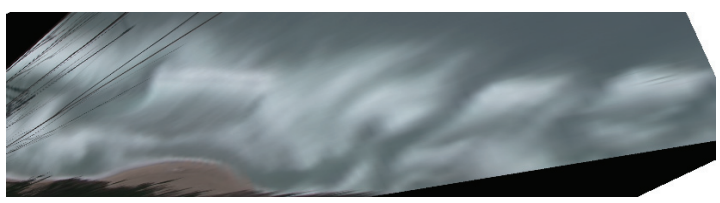

(c) 3 月 30 日

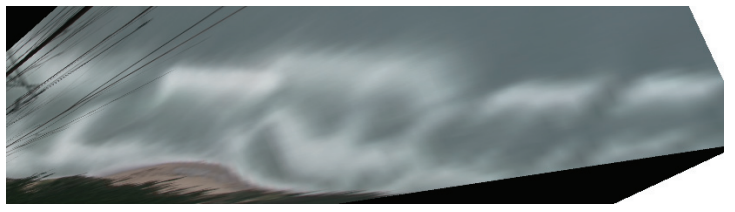

(d) 9 月 7 日

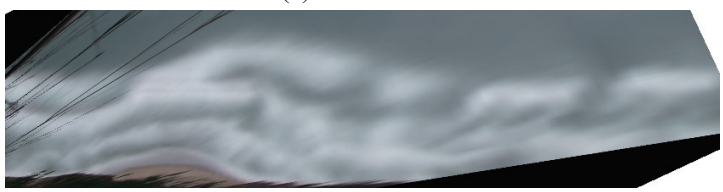

(e) 11 月 16 日

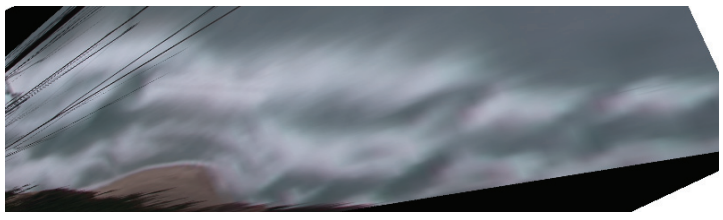

(f) 12 月 9 日

写真-1 人工リーフNo.2 付近の海底地形の変化（2007年）

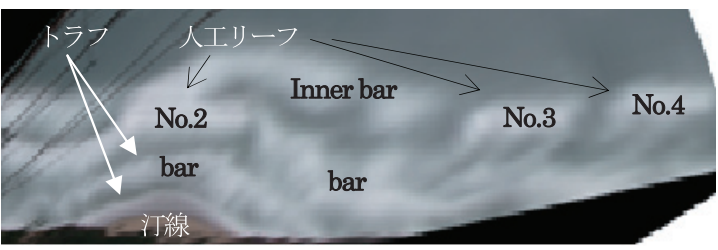

図-2 人工リーフNo.2，3，4 と砂堆（bar）の説明図

（b）高波浪の最盛期で汀線付近から発生した離岸流によ

り（a）の凹状砂州上に複数の澪筋が現れている.

(c) No.2人工リーフの右端沖側にあった砂堆が幾分岸側 に移動している．また汀線付近沿岸方向にはっきりと した澪筋が現れている。

(d) No.2とNo.3の間の砂堆はさらに岸方向に移動してい る.またNo.2 と No.3の人工リーフの間には鳥取海岸全 域にわたる inner barが見える.

(e) (d) のinner barの他に, No.2の人エリーフから岸に 向かう砂州と人工リーフの内側に発達しているトンボ ロの沖側に沿岸砂州が発生して，この部分に3つのbar が存在している。このパターンはよく現れる.

（f）（e）の岸側の2つのbarが一体化し，（a）と同じ凹状 のbar（砂堆）となっている。この砂堆の岸側には岸に 沿って澪筋が現れている.

（a）から（f）を通じて，No.2の人工リーフとトンボロ 状の海岸の間には常時, 岸に沿う砂州が存在し，その岸 側，沖側にはつねに澪筋が存在する。これは人工リーフ の岸側には常時沿岸方向の流れが存在して人エリーフと 岸の間の埋没を防いでいるためと推定される.

\section{3. 列状の人エリーフの場合}

\section{（1）bar と沿岸流系}

図-1のようにNo.3〜No.7までの 5 基の人工リーフは開 口部幅 $100 \mathrm{~m}$ で1列に並んでいる.No.3 とo.8はそれぞ れ2006年，2008年に建設されたので他の人工リーフとは 地形変化に対する影響は幾分異なる. No.3より東側では 人工リーフの沖側にはinner bar は存在しない。写真-2は 2007 年 1 月〜 2 月の約 1 か月の間の barの変化を示した写 

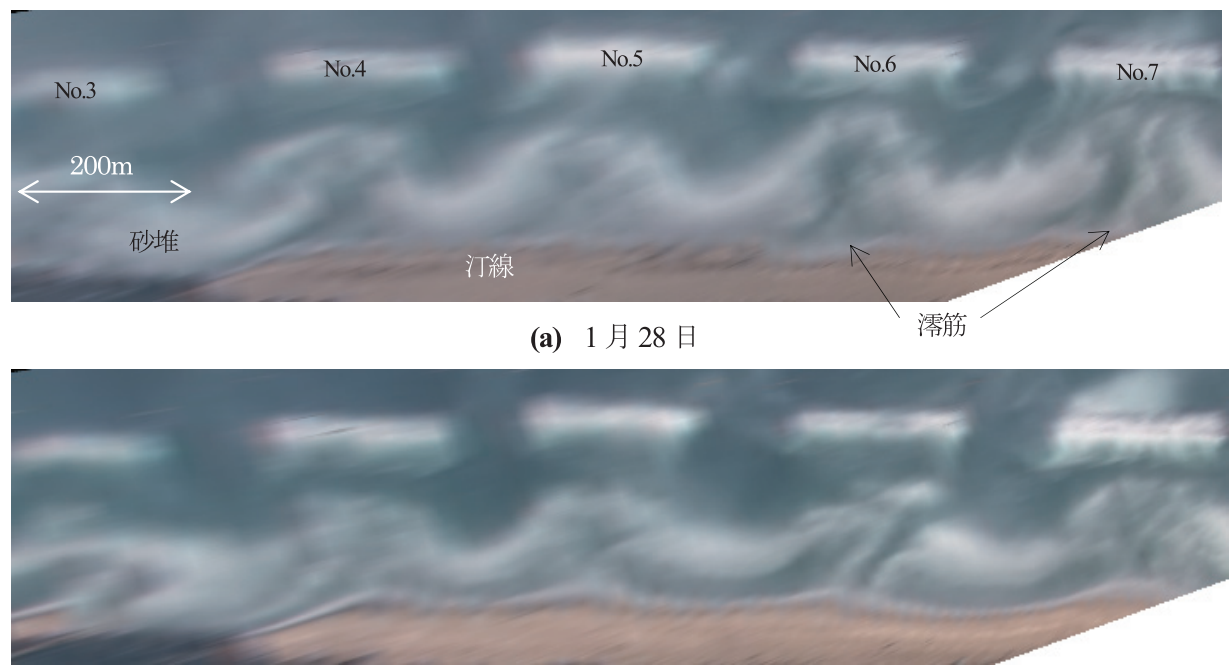

(b) 2 月 12 日

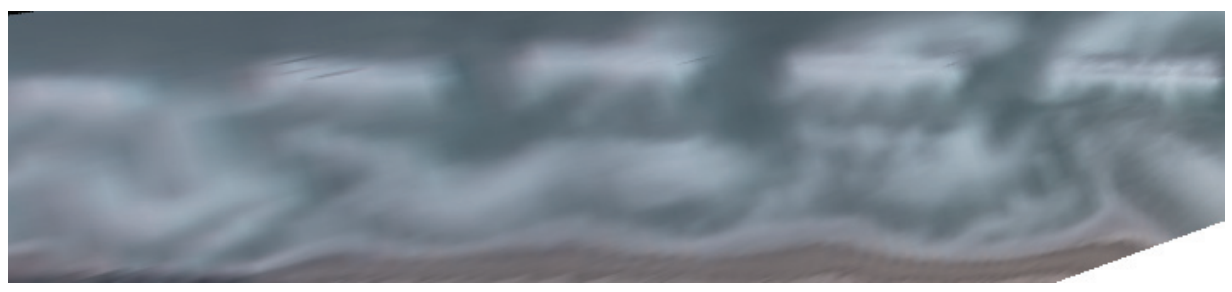

(c) 2 月 22 日

写真-2 人工リーフ岸側のbarの変化

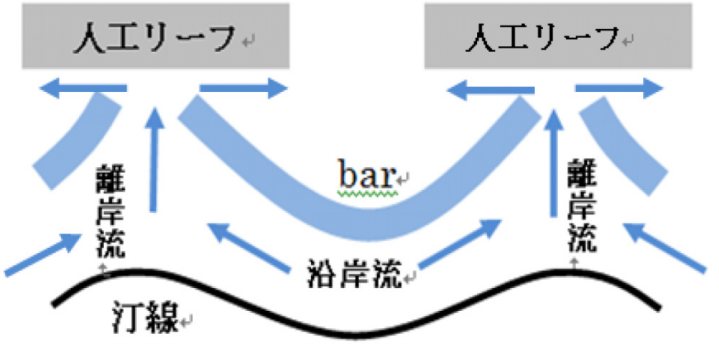

図-3 人工リーフ背後のbar と沿岸流系の模式図

真である. 写真（a）では砂堆は人工リーフの部分でト ンボロのようにも見える．しかしながら（b）に見える ように, 砂堆の岸側には沿岸方向の澪筋が存在する. 澪 筋は人工リーフの位置で沿岸方向から沖向き（人工リー フに向かう方向）に方向が変わっている. すなわち, 汀 線付近では人工リーフ開口部から人工リーフ背後に向か う流れが零筋を形成し, 人工リーフの背後で左右両方か らの流れが合わさって沖向きの流れになる．写真では人 エリーフの背後でトンボロが発生しているように見える が, この部分で沖向きの澪筋が存在し, トンボロは左右 に切れている.これを模式的に示したものが図-3である. この沿岸流系により人工リーフ開口部岸側に沖向きに凹
型の砂堆が発達する.

また, 人工リーフ背後の沖向きの澪筋は常時存在し, ARGUS 画像では砂堆の頂点が人工リーフに達すること は年間を通じてない。したがって人工リーフの岸側に沿 岸方向の流れが存在することが推定される. 高波浪期が 終わり, 静穏期になると凹凸形状を示していた砂堆の頂 点の部分が水平方向に切り取られたようになり, 凹凸形 状が失われて人工リーフ列にほぼ平行な直線状の砂堆と なる (写真- (c)). これに対応して静穏期には高波浪期 に形成されていた汀線の凹凸形状は次第に直線に近い形 状を示すようになる。 これらの変化がかなり短期間に進 行する.すなわちかなり強い沿岸流系の存在が推定され る.このほか岩戸の人工リーフ列では写真-2の左側から 右に向かって海浜の幅が少しずつ広くなる傾向がみら れる。

\section{（2）bar 開口部からの砂の流出}

写真-3 は人工リーフNo.5, 6および7付近のAUGUS 画 像である．各写真は上から 2006年，2007年および2008年 のほほ同じ高波浪期のものである。ここでは示していな いが他の時期のものについても ARGUS 画像はほぼ同じよ うなパターンを示している.これらの写真に共通して, 


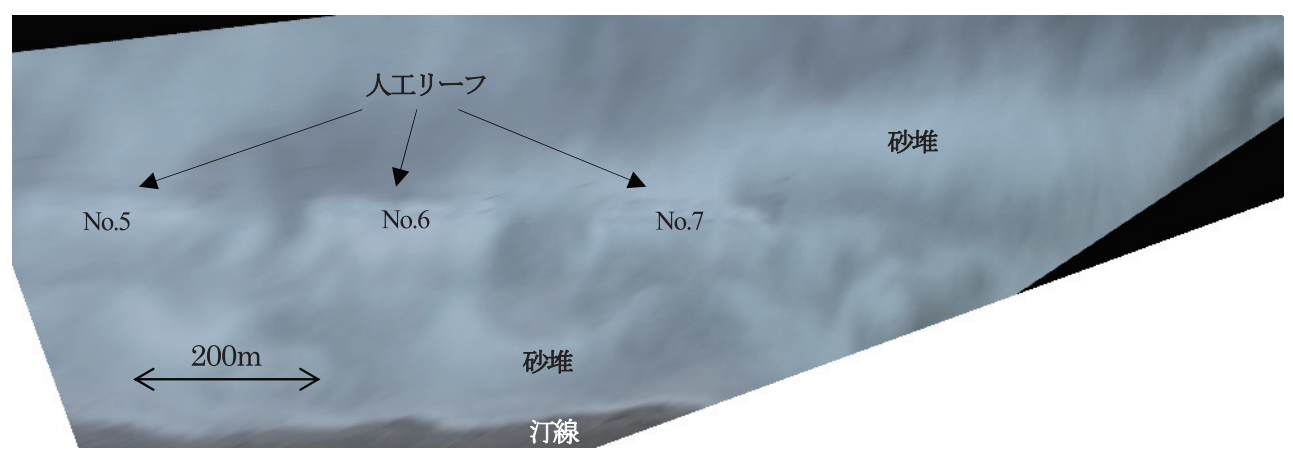

(a) 2006 年 3 月 19 日

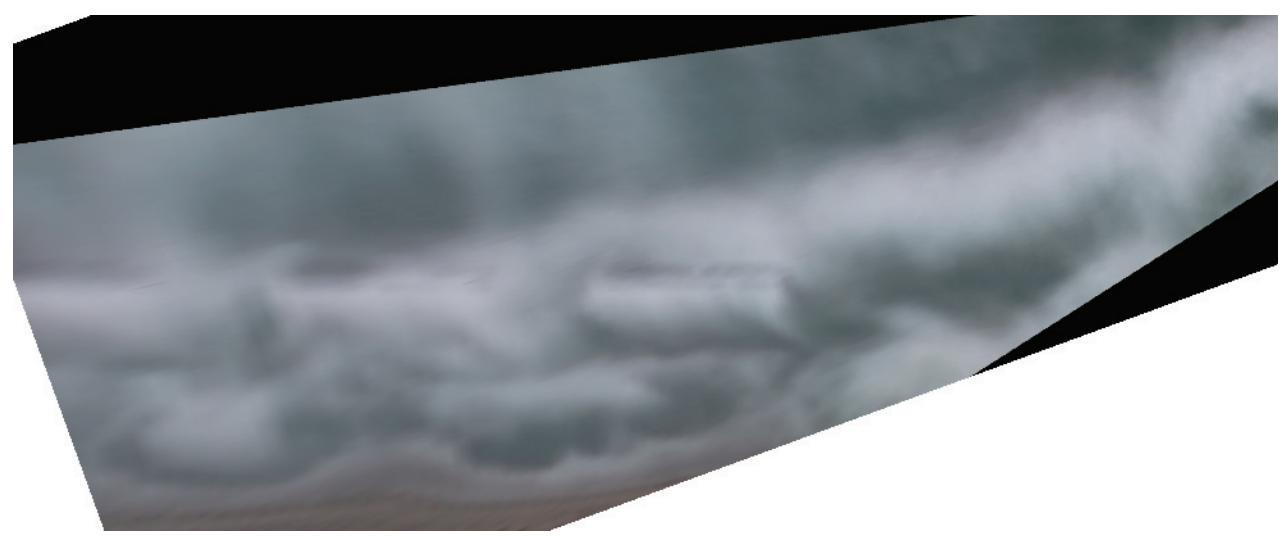

(b) 2007 年 3 月 11 日

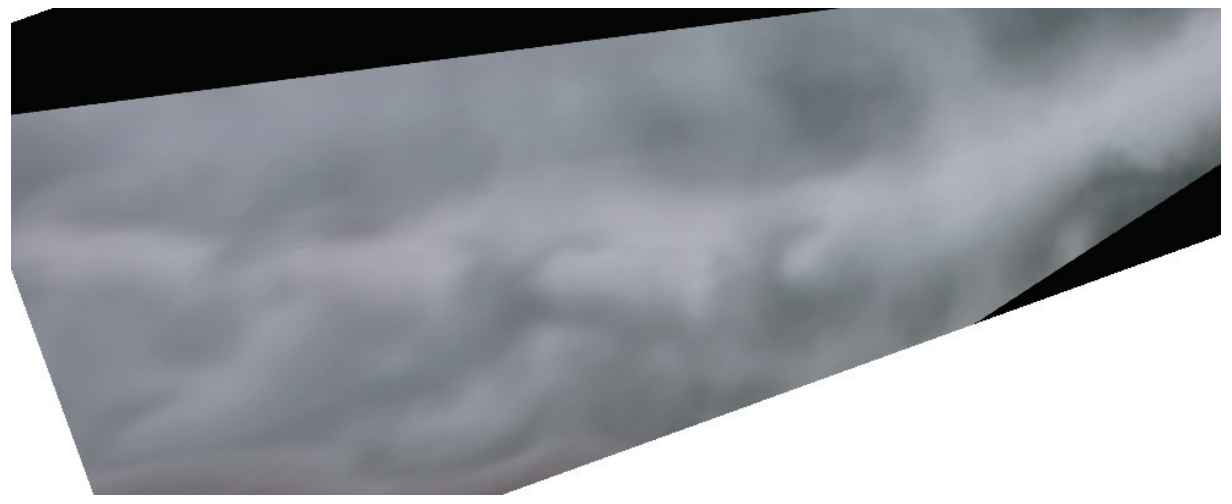

(c) 2008 年 2 月 23 日

写真-3 人エリーフNo.5, 6, 7付近のARGUS 画像

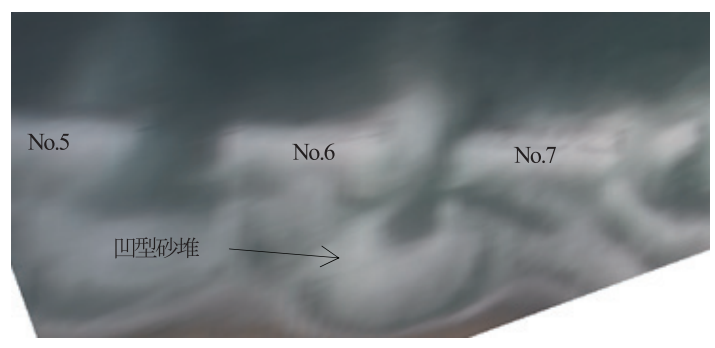

写真-4 人工リーフNo.5, 6, 7付近のARGUS 画像
人工リーフNo.6付近より東（右）方向に砂堆が存在する. 砂堆は人工リーフ列から沖側に離れるように伸びて，鳥 取海岸東端の岩戸漁港の港口部に達している（図-1). 砂 堆の始点は人工リーフNo.6とNo.7 付近である. 写真-4は 2007 年 11 月 23 日の画像であるが, 上の2つの開口部内側 の凹型の砂堆（図-3）から開口部に向けて沖向きの砂堆 がみられ，ここから出た砂が写真-3の人工リーフ沖側の 砂堆の供給源となっていることが推定される。他の ARGUS 画像の検討では, No.5 と No.6の開口部に砂堆がみ 


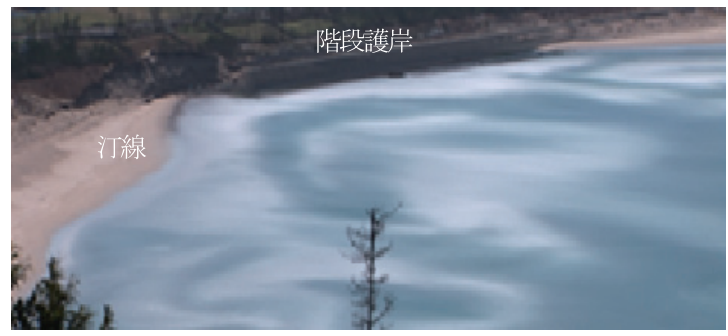

(a) 2006 年 2 月 8 日

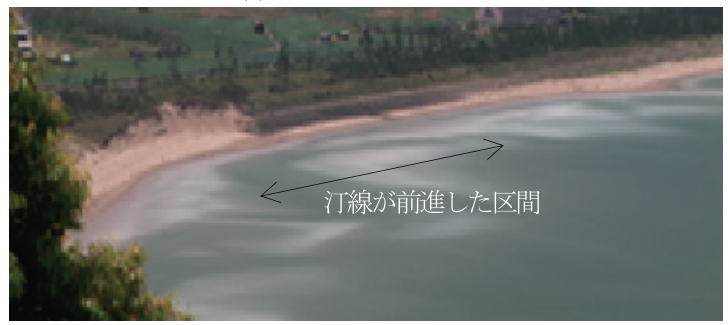

(b) 2007 年 5 月 12 日

写真-5 岩戸海岸の ARGUS 画像（座標変換なし）

られるものもあったが，わずかであり，砂はほぼNo.6と No.7の開口部から沖に抜けているようである。一方, No.7の人工リーフの岸側から前記の岩戸漁港の方向に延 びる砂堆への砂の供給がうかがわれる画像はなかった. 人工リーフ列の岸側の砂の動きについてはそれが明確に わかる画像はなかった。写真-5は人工リーフ列の東側の 岩戸海岸のARGUS 画像である。（a）は2006年2月18日, （b）は2007年 5 月 12 日の画像である.中央部の海岸には 階段護岸が設置されている．写真（a）では階段護岸の東 (画像では左) 側がえぐられている，写真（b）では階段 護岸前面にも砂がついている.この部分は写真-2の人工 リーフ列の東端にあたり，波が直接作用している部分で ある．2004年の観測開始から2006までは写真（a）の状態 が続いていたが2007年になって階段護岸前面の汀線の回 復がみられた．砂の供給は人工リーフ列すなわち西方向 からと推定される。したがって年によっては西側からの 砂の供給があり，汀線が回復する場合がある.

\section{4. 浦富海岸の人エリーフ}

浦富は鳥取砂丘海岸より約 $5 \mathrm{~km}$ 東に位置する海岸であ る.この海岸の湾奥部約 $1 \mathrm{~km}$ が砂浜となっており, この 部分に表-1の(3) 2 基の人工リーフが設置されている. 写真-6はこの海岸のARGUS 画像である. 写真左が海岸, 右が沖側，中央部に下から上に白く伸びているのが 2 基 の人工リーフである. 写真中央部の少し黒い部分が人工 リーフの開口部となっている. 写真より開口部の沖側に

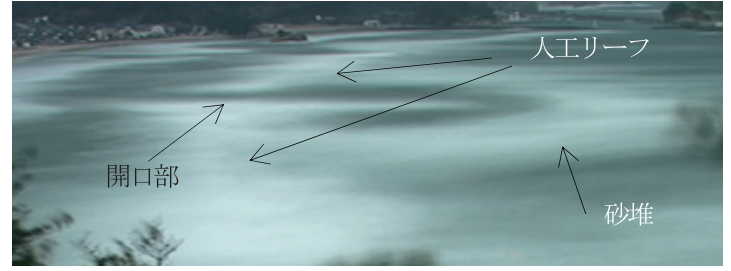

写真-6 浦富海岸のARGUS 画像（座標変換なし）

ほぼ半円状の砂堆の存在がみられる。この砂堆の円弧の 両端では，砂が人工リーフを超えて一部が人工リーフの 岸側に堆積している。この開口部を通じて時折かなり強 い離岸流が観察される. 写真の砂堆はこの離岸流により 輸送されたものと推定される。

\section{5. おわりに}

この研究は著者らが2004年から鳥取砂丘海岸, 浦富海 岸で実施している観測結果の一部を示したもので，人工 リーフ周辺の海底地形について検討を行った結果を示し たものである。その結果，鳥取海岸に設置されている人 エリーフでは次のようなことが分かった。

(a) 人工リーフ設置水深が現地海岸のinner barより岸側 の場合, その沖側にinner barが形成される. 設置水深 がinner barより沖側の場合，人工リーフの沖側には bar は形成されない.

（b）人工リーフの岸側にはどの場合も砂堆（bar）が現れ, その岸沖両側に澪筋が存在する.

（c）人工リーフが列状に設置されている場合，高波浪時 にリーフ開口部付近で汀線沿い沿岸方向, 人工リーフ の中央部で沖に向かう澪筋が現れる.この結果，人工 リーフ開口部内側に沖に凹状の砂堆が形成される.

（d）人工リーフ列のほぼ東端の人工リーフ開口部より人 エリーフ列から沖側東方（岩戸港方向）に延びる砂堆 が現れる。この部分では人工リーフ開口部から砂が沖 向きに出ていることが推定される.しかし，これより 西側の人工リーフ開口部からの砂の流出がうかがわれ る画像の数は非常に少なかった。

\section{参 考 文 献}

木村 晃・大野賢一（2006）：鳥取海岸における海底地形の短 期変化について, 海岸工学論文集, 第 53巻, pp.571-595.

木村 晃・大野賢一（2007）：鳥取海岸における沿岸砂州の短 期変化について，海岸工学論文集，第 54巻，pp.666-670.

木村 晃・大野賢一 (2008)：鳥取海岸沿岸の outer barの短期 変化特性について, 海岸工学論文集, 第 55 巻, pp.716720 .

木村 晃・木村照子（2009）：鳥取砂丘海岸のカスプの波長に ついて, 海岸工学論文集, 第56巻, pp.581-585. 